\title{
Differential expression of alternatively spliced mRNA forms of the insulin-like growth factor 1 receptor in human neuroendocrine tumors
}

\author{
LORENZA VITALE ${ }^{1}$, LUCA LENZI $^{1}$, SHANE A. HUNTSMAN ${ }^{2}$, SILVIA CANAIDER ${ }^{1}$, \\ FLAVIA FRABETTI ${ }^{1}$, RAFFAELLA CASADEI ${ }^{1}$, FEDERICA FACCHIN ${ }^{1}$, \\ PAOLO CARINCI $^{1}$, MARIA ZANNOTTI ${ }^{1}$, DOMENICO COPPOLA ${ }^{2}$ and PIERLUIGI STRIPPOLI ${ }^{1}$ \\ ${ }^{1}$ Dipartimento di Istologia, Embriologia e Biologia Applicata, Università di Bologna, Via Belmeloro 8 , \\ I-40126 Bologna, Italy; ${ }^{2}$ 'H. Lee Moffitt' Cancer Center, University of South Florida, Tampa, FL, USA
}

Received October 17, 2005; Accepted November 14, 2005

\begin{abstract}
The activation of the insulin-like growth factor 1/IGF1 receptor system (IGF1/IGF1R) is a critical event in the transformation and tumorigenicity processes in a wide variety of human tumors. The IGF1/IGF1R system has been recently studied in carcinoid tumors that often arise in the gastrointestinal tract; these tumors are characterized by hypersecretion of bioamines and neuropeptides, leading to functional tumor disease. Two alternatively spliced $I G F 1 R$ mRNA transcripts have been described to differ by only three nucleotides (CAG) in the coding sequence, resulting in an amino-acid change from the originally described Thr-Gly to an Arg in the extracellular portion of the receptor $\beta$ subunit. In transfected Chinese hamster ovary cells, the form without CAG (CAG) exhibited an approximate 2-fold increase in IGF1 stimulation of activities required for its mitogenic properties. In this study, we examine the relative expression of the two $I G F 1 R$ mRNA isoforms by a semiquantitative RT-PCR approach using highly standardized conditions, $\beta-2$ microglobulin $(B 2 M)$ as a reference gene and gel imaging analysis. We analyzed a large series of human neuroendocrine tumors (32 samples) and 9 normal tissues. A significant higher expression of both isoforms in the tumor samples ( 2-fold increase) was found, while a constant $\mathrm{CAG}^{+} / \mathrm{CAG}^{-} I G F 1 R$ mRNA isoforms of an approximate 3:1 ratio was observed in all tumoral and normal cell types studied. The phylogenetic study of the IGFIR locus in several species suggests that human IGFIR $\mathrm{CAG}^{-}$mRNA isoform is evolutionarily more recent compared to the IGFIR $\mathrm{CAG}^{+}$mRNA isoform and it
\end{abstract}

Correspondence to: Dr Pierluigi Strippoli, Dipartimento di Istologia, Embriologia e Biologia applicata, Via Belmeloro 8, I-40126 Bologna, Italy

E-mail: pierluigi.strippoli@unibo.it

Key words: IGFIR, neuroendocrine tumors, 'subtle' alternative splicing, semiquantitative PCR could be used by the splicing apparatus at this intron/exon junction with a lower efficiency. This study highlights the relevance of IGFIR mRNA expression in neuroendocrine tumor cells, and the constant presence of 'subtle' alternative splicing for the IGFIR locus.

\section{Introduction}

The insulin-like growth factor 1 receptor $(I G F 1 R)$ gene (1) encodes for a transmembrane receptor with tyrosine kinase activity which binds insulin-like growth factor with a high affinity. In the last decade, IGF1R has emerged as a key regulator of mitogenesis and tumorigenicity, because of its crucial role in cell transformation, tumor invasion, metastasis, and cell survival enhancement due to anti-apoptotic activity (2). IGF1R is a heterotetramer composed of two extracellular $\alpha$ subunits containing the ligand-binding site and two transmembrane $\beta$ subunits harboring intracellular tyrosine kinase activity, connected by disulfide bonds. The activation of the insulin-like growth factor $1 / \mathrm{IGF} 1$ receptor system (IGF1/ IGF1R) has emerged as a critical event in the transformation and tumorigenicity of a wide variety of tumor types (3-10). This type of experimentation has revealed that $I G F I R$ is usually overexpressed in highly invasive and metastasizing tumors (2).

The IGF1/IGF1R system has been recently studied also in carcinoid tumors $(11,12)$ : when these tumors arise in the gastrointestinal tract they may be characterized by hypersecretion of bioamines and neuropeptides which lead to functional tumor disease. The human BON gastrointestinal carcinoid tumor cell line has been seen to express functionally active insulin-like growth factor-1 receptors and to secrete IGF1, suggesting an autocrine action of this growth factor. Moreover, IGF1 induces a marked increase of chromogranin A secretion, a typical marker protein for neuroendocrine secretion, suggesting the existence of an autocrine IGF1 loop regulating basal neuroendocrine secretion in BON cells (11). The activation of the raf-1/MEK1 pathway may reverse the effect of IGF1 treatment in BON cells by the depletion of intracellular chromogranin A (12). In addition, IGF1 stimulates anchorage-dependent and anchorage-independent growth of 
BON cells and endogenously released IGF1 was found to be largely responsible for autonomous growth of BON cells in serum-free medium (11). The mRNA expression of several IGF-type factors and receptors has been studied in 37 gastroenteropancreatic neuroendocrine tumors by qualitative RT-PCR showing positivity for IGFIR mRNA expression in $89 \%$ of 9 gastrinomas, $90 \%$ of 10 insulinomas, $67 \%$ of 9 carcinoid syndromes and $33 \%$ of 9 functionally inactive tumors (13).

Interestingly, two alternatively spliced human IGFIR mRNA transcripts have been described: they differ by only three nucleotides (CAG), due to possible retaining in intron 13 of the first three bases of exon 14 (CAG), resulting in an amino-acid coding sequence change from the originally described Thr-Gly to an Arg in the extracellular portion of the receptor $\beta$ subunit (14). IGFIR lacking CAG bases will be named $I G F I R \mathrm{CAG}^{-}$and $I G F I R$ longest form (with CAG bases) will be named $\mathrm{CAG}^{+}$. In transfected Chinese hamster ovary (CHO) cells, the $\mathrm{CAG}^{-}$form exhibits an approximately 2-fold increase in IGF1 stimulation of several activities, in particular receptor autophosphorylation, a strict requirement for its mitogenic properties (8), and thymidine incorporation; the slower rate of receptor internalization could cause or contribute to the increase of tyrosine phosphorylation.

To date, no data are available about the relative expression of the IGFIR $\mathrm{CAG}^{+} / \mathrm{CAG}^{-}$isoforms in human tumors. The aim of this work is to study for the first time the relative expression of the two IGFIR mRNA isoforms by a semiquantitative RT-PCR approach in a large series of human neuroendocrine carcinomas of different grade. We demonstrate a significantly higher expression of both isoforms in the studied tumors, as compared to normal tissue, in the presence of a constant IGFIR mRNA $\mathrm{CAG}^{+} / \mathrm{CAG}^{-}$rate in all studied cell types.

\section{Materials and methods}

Sample collection. Sample selection was focused on neuroendocrine tumors from multiple anatomic sites with varying differentiation grades: well-differentiated $(n=10)$, moderatelydifferentiated $(n=4)$, poorly-differentiated $(n=10)$ and islet cell carcinomas $(n=8)$. The specimens were obtained from an equal number of male and female subjects $(n=16)$ with ages ranging between 43 and 79 years old (mean age of 63.65 years) (Table I). Representative portions of thirty-two tumor specimens collected for the H. Lee Moffitt Cancer Center and Research Institute (Tampa, FL) Tissue Procurement Facility under institutional review board protocols were used. The resection-to-preservation (freezing) time was kept to less than $20 \mathrm{~min}$. Sample storage consisted of liquid nitrogen $(n=30)$ and $-80^{\circ} \mathrm{C}(\mathrm{n}=2)$ for a mean storage period of 41.65 months. Prior to RNA isolation, twelve of these tumor samples underwent independent pathological review by a single pathologist (DC) and were macrodissected while frozen to select tumorrich areas and decrease the amount of stroma and non-neoplastic elements surrounding the target tumor tissue.

RNA sources. Total RNA from the study samples was extracted using TRIzol (Invitrogen Corp., Carlsbad, CA) following the manufacturer's protocol. The main histological features of the NE tumors are shown in Table I.
Due to the absence of tissue entirely composed of APUD (amine precursor uptake and decarboxylation) cells, which are by definition part of a diffuse system of cells, 9 commercial total RNA samples from several whole normal human organs have been used as controls: prostate (pool of 16 normal adult whole prostates), brain (one normal adult whole brain), heart (one normal adult whole heart), colon (pool of 2 normal adult colons), small intestine (pool of 2 normal adult small intestines), stomach (pool of 15 normal adult stomachs), thymus (pool of 13 normal adult thymuses), skeletal muscle (pool of 2 normal adult skeletal muscles), testis (pool of 45 normal adult testes). All RNA samples were purchased from BD Biosciences Clontech (Palo Alto, CA, USA).

RNA was quantified by both UV spectrophotometry and standard agarose gel. Quantification of electrophoresed RNA was obtained in comparison with standard markers by the gel imaging system, Gel Doc 2000 (Bio-Rad, Hercules, CA, USA).

Primer design. The primers for amplifications were designed using Amplify software (15), following standard criteria (16). The data source for primer design was the GenBank sequence NM_000875, Homo sapiens insulin-like growth factor 1 receptor (IGF1R), mRNA. In particular, for semiquantitative IGF1R $\mathrm{CAG}^{+} / \mathrm{CAG}^{-}$analysis, we designed three primers: a reverse primer common to both gene forms (\#1 5'-AGCGC TGAAGTACTCCGGGTTCAC-3') and two forward primers specific for $\mathrm{CAG}^{+}$and $\mathrm{CAG}^{-}$forms, respectively. Each forward oligonucleotide was specific for only one of the two isoforms, harboring two mismatches at the last three bases of the $3^{\prime}$ end, one being the 3'-residue, with respect to the sequence of the other isoform (\#2 5'-TTCTTCTATGTCCAGGCCAAAA CAG-3' for the IGFIR $\mathrm{CAG}^{+}$form, \#3 5'-TTCTTCTATGTC CAGGCCAAAAGAT-3' for the IGF $1 R \mathrm{CAG}^{-}$form). The size of PCR product obtained was 189 bp with primers \#1 and \#2, and 186 bp with primers \#1 and \#3.

To amplify the $B 2 M$ housekeeping gene for RNA quantity normalization, we used forward primer \#4 5'-GCGGGCATT CCTGAAGCTGACAGCA-3' and reverse primer \#5 5'-TAC ATCAAACATGGAGACAGCACTC-3', with an expected PCR product size of $586 \mathrm{bp}$.

$R T-P C R$. For all samples, total RNA $(2 \mu \mathrm{g})$ was reverse transcribed at $37^{\circ} \mathrm{C}$ for $60 \mathrm{~min}$ in $50 \mu \mathrm{l}$ of final volume by cloned Moloney murine leukemia virus reverse-transcriptase $400 \mathrm{U}$ (Promega, Madison, WI; used with companion buffer), $2.5 \mu \mathrm{M}$ oligo dT-15, $2 \mu \mathrm{M}$ random hexamers and $500 \mu \mathrm{M}$ each dNTP.

PCR experiments were performed in $50 \mu 1$ of final volume, containing $5 \mu \mathrm{l}$ of reverse transcription mix, $1 \mathrm{U}$ of Taq Polymerase (Takara, Shiga, Japan) with companion reagents (0.2 mM each dNTP, $2 \mathrm{mM} \mathrm{MgCl}_{2}, 1 \mathrm{X}$ PCR buffer), and $0.2 \mu \mathrm{M}$ of each primer.

To uniform all PCR reactions, we performed a unique mix with PCR buffer $1 \mathrm{X}$, dNTPs, $\mathrm{MgCl}_{2}$ and Taq Polymerase. Subsequently this mix was divided into three aliquots and a different primer pair was added to each one. The cDNA samples were added after every mix was divided in single tubes. Each PCR reaction was performed in duplicate. In preliminary PCR experiments we evaluated PCR products 
Table I. RNA sample list.

\begin{tabular}{|c|c|c|c|c|c|c|c|}
\hline Sample & Race & Age & Sex & $\begin{array}{l}\text { Storage time } \\
\text { (months) }\end{array}$ & Diagnosis & Site & $\begin{array}{l}\text { Differentiation } \\
\text { grade }\end{array}$ \\
\hline NE 1 & WNH & 75 & $\mathrm{M}$ & 50 & Carcinoma metastatic NE & Liver, right & Well \\
\hline NE 2 & WNH & 59 & $\mathrm{~F}$ & 30 & Neoplasm NE metastatic & Liver, left lobe & Well \\
\hline NE 3 & WNH & 59 & $\mathrm{~F}$ & 30 & Neoplasm NE & Bowel, small & Well \\
\hline NE 4 & WNH & 64 & $\mathrm{~F}$ & 31 & NE tumor $(100 \%)$ & Liver, right & Well \\
\hline NE 5 & WNH & 64 & $\mathrm{~F}$ & 31 & NE tumor $(98 \%)$ & Liver, left & Well \\
\hline NE 6 & WNH & 64 & $\mathrm{~F}$ & 31 & NE tumor $(98 \%)$ & Liver, right & Well \\
\hline NE 7 & WNH & 66 & $\mathrm{~F}$ & 11 & NE metastatic tumor (98\%) & Liver & Well \\
\hline NE 8 & WNH & 66 & $\mathrm{~F}$ & 11 & NE metastatic tumor $(100 \%)$ & Liver & Well \\
\hline NE 9 & WNH & 66 & $\mathrm{~F}$ & 11 & $\begin{array}{l}\text { NE metastatic tumor }(95 \%) \\
\text { involving muscularis propria }\end{array}$ & Colon & Well \\
\hline NE 10 & WNH & 70 & M & 6 & Carcinoma NE (95\%, stroma 5\%) & Pancreas & Well \\
\hline NE 11 & WNH & 60 & $\mathrm{~F}$ & 34 & Carcinoma large cell NE & Breast, right & Moderate \\
\hline NE 12 & WNH & 64 & M & 21 & $\begin{array}{l}\text { Adenocarcinoma metastatic, } \\
\text { NE features ( } 85 \% \text { tumor) }\end{array}$ & $\begin{array}{l}\text { Liver, segment } \\
7 \text { and } 8\end{array}$ & Moderate \\
\hline NE 13 & WNH & 60 & M & 12 & NE tumor $(100 \%)$ & Omental nodule & Moderate \\
\hline NE 14 & WNH & 55 & M & 20 & NE tumor $(100 \%)$ & Liver & Moderate \\
\hline NE 15 & WNH & 79 & M & 104 & NE carcinoma & $\begin{array}{l}\text { Abdominal } \\
\text { perianal mass }\end{array}$ & Poor \\
\hline NE 16 & WNH & 61 & $\mathrm{~F}$ & 100 & Carcinoma with NE features & Neck, right (HN) & Poor \\
\hline NE 17 & WNH & 59 & M & 83 & Small cell NE carcinoma & $\begin{array}{l}\text { Parotid, right, } \\
\text { temporal (HN) }\end{array}$ & Poor \\
\hline NE 18 & WNH & 63 & $\mathrm{~F}$ & 75 & $\begin{array}{l}\text { Infiltrating carcinoma } \\
\text { with NE features, grade III }\end{array}$ & Breast, right & Poor \\
\hline NE 19 & $\mathrm{U}$ & 79 & M & 66 & Small cell NE carcinoma & Groin & Poor \\
\hline NE 20 & WNH & 69 & M & 31 & Carcinoma NE & Liver, left lobe & Poor \\
\hline NE 21 & WNH & 70 & $\mathrm{~F}$ & 30 & Carcinoma with NE features & Ovary, right & Poor \\
\hline NE 22 & WNH & 60 & $\mathrm{~F}$ & 25 & Carcinoma NE of breast origin & Peristernal mass & Poor \\
\hline NE 23 & WNH & 64 & M & 56 & $\begin{array}{l}\text { Squamous cell carcinoma } \\
\text { with NE features }\end{array}$ & Lung, left & Poor \\
\hline NE 24 & WNH & 66 & $\mathrm{~F}$ & 55 & $\begin{array}{l}\text { Infiltrating ductal carcinoma } \\
\text { with NE features }\end{array}$ & Breast, right & Poor \\
\hline NE 25 & $\mathrm{U}$ & 54 & M & 79 & NE carcinoma & Pancreas & Islet \\
\hline NE 26 & $\mathrm{U}$ & 56 & M & 56 & $\begin{array}{l}\text { NE carcinoma metastatic, } \\
\text { consistent with pancreatic primary }\end{array}$ & Liver & Islet \\
\hline NE 27 & WNH & 48 & M & 29 & $\begin{array}{l}\text { NE tumor with trabecular and } \\
\text { gyriform pattern of growth }\end{array}$ & Pancreas, head of & Islet \\
\hline NE 28 & WNH & 77 & $\mathrm{~F}$ & 60 & $\begin{array}{l}\text { Pancreatic ductal adenocarcinoma } \\
\text { with NE differentiations }\end{array}$ & Pancreas & Islet \\
\hline NE 29 & $\mathrm{U}$ & 52 & M & 72 & Gastrinoma (islet cell tumor) & Pancreas & Islet \\
\hline NE 30 & WNH & 70 & M & 48 & Carcinoma islet cell type, Mod. & Pancreas & Islet \\
\hline NE 31 & WNH & 75 & M & 17 & Pancreatic islet cell tumor $(100 \%)$ & Pancreas & Islet \\
\hline NE 32 & WNH & 43 & $\mathrm{~F}$ & 15 & Islet cell metastatic tumor (100\%) & Abdominal wall & Islet \\
\hline
\end{tabular}

NE, neuroendocrine; WNH, white non-hispanic; U, unknown; M, male; F, female; HN, head and neck; Islet, Islet cell carcinoma. Percentage of tumor (not stromal) cells is given in parenthesis, when known. All tumor specimens were stored under liquid nitrogen, except NE 15 and $\mathrm{NE} 16$, which were stored at $-80^{\circ} \mathrm{C}$. 
after $20,25,30,35,40$ and 45 cycles (data not shown), in order to find the conditions allowing quantification of $B 2 M, I G F 1 R \mathrm{CAG}^{+}$and IGFIR CAG- RT-PCR products, respectively, at the maximum distance from the cycles corresponding to the reaction plateau.

PCR reactions were performed with high stringency: an initial denaturation step of $2 \mathrm{~min}$ at $94^{\circ} \mathrm{C}$ was followed by amplification for $25(B 2 M)$ or 35 (IGF1R $\mathrm{CAG}^{+}$or $\left.\mathrm{CAG}^{-}\right)$ cycles $\left(30 \mathrm{sec}\right.$ at $94^{\circ} \mathrm{C}, 30 \mathrm{sec}$ at $63^{\circ} \mathrm{C}, 45 \mathrm{sec}$ at $\left.72^{\circ} \mathrm{C}\right)$, and a final extension for $7 \mathrm{~min}$ at $72^{\circ} \mathrm{C}$.

Gel imaging. Ten- $\mu 1$ aliquots of each PCR product were separated on $1.7 \%$ agarose TAE gels. B2M, IGFIR $\mathrm{CAG}^{+}$and $I G F 1 R$ CAG- RT-PCR products from the same RNA samples were separated on the same gel. Marker M5 (Fermentas, Hanover, MD, USA) at two different dilutions was used as a quantitative reference. After separation, gels were stained in TAE buffer containing ethidium bromide $(0.5 \mu \mathrm{g} / \mathrm{ml})$ and detected under ultraviolet light in unsaturated pixel modality with the Gel Doc 2000 Imaging System. Digital images were quantitated and analyzed by using Quantity One software (Bio-Rad, Hercules, CA, USA).

Intensity values of the PCR product bands were calculated in comparison with a regression line with correlation coefficient $\geq 0.99$ generated from measurements of at least four Marker M5 bands of different concentration values. In particular we used the 'Volume Rect Tool' function to acquire intensity pixel data for each band. Gel image background was always subtracted.

Statistical analysis. The mean for each replicate data point and, to normalize the IGF1R expression level, the IGF1R/B2M product mass ratio were determined. Statistical analysis was performed using StatView software. Unpaired t-test was used to compare normalized IGFIR expression levels between normal and tumoral tissues, as well as to compare the relative expression of IGFIR $\mathrm{CAG}^{+}$and $\mathrm{CAG}^{-}$isoforms.

ANOVA test and Fisher's post hoc test were performed to compare IGFIR expression levels (for $\mathrm{CAG}^{+}$isoform, $\mathrm{CAG}^{-}$ isoform and $\mathrm{CAG}^{+}: \mathrm{CAG}^{-}$ratio) in each different histological subclass of tumors (10 well-differentiated; 4 moderately differentiated; 10 poorly differentiated; 8 islet cell carcinomas; 9 normal tissues). Differences were considered significant at $\mathrm{p}<0.05$.

Bioinformatic analysis. In order to study the evolution of 'subtle' splicing (17) of the IGFIR mRNA $\left(\mathrm{CAG}^{+}\right.$and $\mathrm{CAG}^{-}$ isoforms), we analyzed the IGFIR mRNA sequence encompassing the point alternatively spliced (GenBank \#NM_000875, from base 2600 to 3000 ) using BLASTN software with default parameters and the following GenBank divisions: 'nr' (nonredundant), 'human ESTs' (espressed sequence tags), 'mouse ESTs' and 'other ESTs' database sequences.

\section{Results}

$R T-P C R$. The RT-PCR amplification products for $B 2 M$, $I G F 1 R \mathrm{CAG}^{+}$and IGFIR CAG- mRNAs were successfully obtained from the 32 NE RNA samples and from 9 normal RNA controls. In all cases, gel electrophoresis analysis revealed single bands of the expected size (Fig. 1).

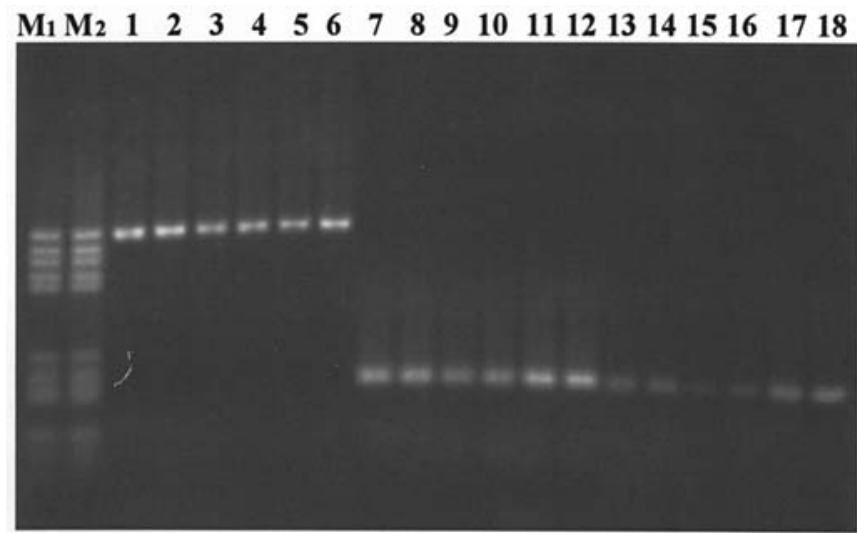

Figure 1. Exemplificative agarose gel loaded with duplicated RT-PCR products: $B 2 M$ (lanes 1-6, $586 \mathrm{bp}$ ), IGF1R $\mathrm{CAG}^{+}$(lanes 7-12, $189 \mathrm{bp}$ ), and $I G F 1 R \mathrm{CAG}^{-}$(lanes 13-18, $186 \mathrm{bp}$ ) mRNAs for samples NE 15, NE 16 and NE 17. DNA M5 markers ( $\mathrm{M}_{1}$ and $\mathrm{M}_{2}, 250 \mathrm{ng}$ and $500 \mathrm{ng}$ respectively) were used for quantification by Gel Doc software.

Gel imaging. The gel images acquired in UV light and in 'unsaturated pixel' mode have been analyzed. RT-PCR products of $B 2 M, I G F 1 R \mathrm{CAG}^{+}$and $I G F 1 R \mathrm{CAG}^{-} \mathrm{mRNAs}$ obtained from the same sample were electrophoresed in the same gel.

This process generated two replicate data points, expressed as PCR product ng, which were used for subsequent elaborations.

Duplicate products for each gene were compared to evaluate the method reliability. The percentage of difference between the two replicate measurements was lower than $8 \%$ for all genes in all samples, except for IGF1R CAG- isoform values in normal samples, where the $25.26 \%$ mean difference was due to the presence of values situated near to the lowest detectable level. The mean value of the two measurements was therefore routinely used in the statistical comparisons.

Statistical analysis. The difference in B2M RT-PCR product masses (in ng) at 25 cycles of amplification was examined between the groups of tumoral and normal samples by unpaired t-test; it was not statistically significant (mean \pm standard

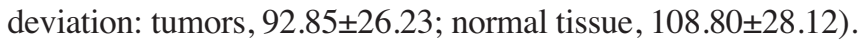

All differences among IGF1R mRNA isoform expression levels are referred to RT-PCR product mass normalized as described in Materials and methods.

The difference in $I G F 1 R \mathrm{CAG}^{+}: \mathrm{CAG}^{-}$mRNA isoform ratio between tumors and normal tissue was not significant (mean \pm standard deviation: tumors, 3.04 \pm 4.57 ; normal tissue, $2.82 \pm 1.06$ ). Values for the tumor group become $2.25 \pm 0.99$ if the outlier value of $27.54 \mathrm{CAG}^{+}: \mathrm{CAG}^{-}$ratio is removed because it derives from the NE 16 unique neck tumor sample which gave two replicate data points at the minimum detected level in this study (mean $1.86 \mathrm{ng}$ for $\mathrm{CAG}^{-}$isoform).

The difference in IGFIR $\mathrm{CAG}^{+}$expression levels between tumors and normal tissue was significant $(\mathrm{p}=0.018$; mean \pm standard deviation: tumors, $1.17 \pm 0.66$; normal tissue, $0.61 \pm 0.24)$, and difference of the $I G F 1 R \mathrm{CAG}^{-}$expression level between tumors and normal tissue was highly significant $(\mathrm{p}=0.0001$; mean \pm standard deviation: tumors, $0.60 \pm 0.42$; normal tissue, $0.24 \pm 0.09)$. 
Table II. GenBank accession numbers of IGFIR mRNA-related sequences found by bioinformatic analysis (non-redundant and EST databases).

\begin{tabular}{|c|c|c|c|c|}
\hline \multirow{2}{*}{$\begin{array}{l}\text { Database: } \\
\text { Isoform: }\end{array}$} & \multicolumn{2}{|c|}{ Non-redundant } & \multicolumn{2}{|c|}{ ESTs } \\
\hline & $\mathrm{CAG}^{+}$ & $\mathrm{CAG}^{-}$ & $\mathrm{CAG}^{+}$ & $\mathrm{CAG}^{-}$ \\
\hline \multirow[t]{3}{*}{ Homo sapiens } & X04434 (placenta) & & BU849760 (Tca) & CN414639 (ESC) \\
\hline & AY429545 & - & BU848806 (Tca) & CX760537 (PCL) \\
\hline & & & AA100052 (Pca) & BU071909 (I) \\
\hline Pongo pygmaeus & CR858259 (kidney) & - & - & - \\
\hline
\end{tabular}

\begin{tabular}{lll}
\hline Database: & Non-redundant & ESTs
\end{tabular}

Callithrix jacchus

Sus scrofa

NM_214172

AB003362 (blood)

U58370 (skeletal muscle)

Equus caballus

Bos taurus

X54980 (kidney)

Ovis aries

Canis familiaris

Mus musculus

\author{
AY162434 (placenta) \\ XM_545828 \\ NM_010513 \\ AF056187 \\ AC101879 \\ AC 125275
}

\section{Rattus norvegicus

\section{BE030869 (pooled) \\ BE030868 (pooled) \\ BE030885 (pooled)}

CX596610 (articular cartilage)

CK772764 (pooled)
BE752096 (pooled)
AJ819671 (blood)

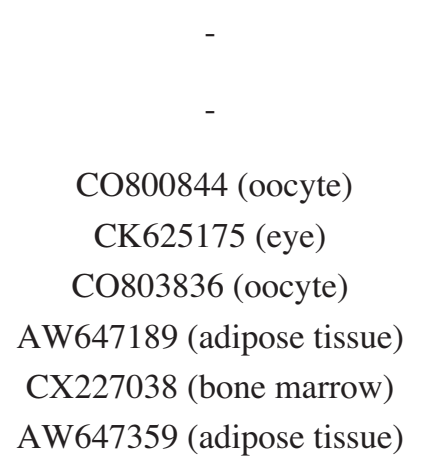

Source of tissue is given in parenthesis when known. Tca, teratocarcinoma; Pca, pancreas adenocarcinoma; ESC, embryo stem cells; PCL, pluripotent cell line; I, insulinoma.

The difference among subclasses derived from histological grading (well-, moderately or poorly differentiated and islet cell carcinomas) was analyzed by ANOVA test and it was not statistically significant for $\mathrm{CAG}^{+}, \mathrm{CAG}^{-}$and $\mathrm{CAG}^{+} / \mathrm{CAG}^{-}$ isoform expression levels.

Bioinformatic analysis. Bioinformatic analysis was conducted by using database versions available on February 2005. In the 'nr' database, only two human mRNA sequences encompassing the variant splice point were found, both relating to the first described $\mathrm{CAG}^{+}$isoform. In the 'human ESTs' database, we identified 6 mRNA sequences related to $I G F 1 R$ assignable to one of the two isoforms: 3 entries with the $\mathrm{CAG}^{+}$sequence and 3 entries with the $\mathrm{CAG}^{-}$sequence (Table II). Fig. 2 shows the alignment of nucleotide sequences present in the GenBank database and encompassing the $\mathrm{CAG}^{+} / \mathrm{CAG}^{-}$exon junction .

The sequence of murine $I G F 1 R$ at a genomic level is not consistent with the possibility of an alternative splicing as in humans because only one $\mathrm{CAG}$ sequence, therefore one acceptor splice site $(\mathrm{AG})$, is present at the 3 ' intronic boundary and the next exon begins with the CGA sequence (CAG*CGA, where $*$ indicates the intron/exon boundary). 


\begin{tabular}{|c|c|c|c|c|c|}
\hline \multirow{3}{*}{$\frac{\text { Species }}{\text { Homo sapiens (CAG+) }}$} & \multirow{3}{*}{$\begin{array}{l}\text { GenBank } n^{\circ} \\
\text { NM_000875 }\end{array}$} & \multicolumn{3}{|c|}{ Sequence } & \multirow{2}{*}{$\begin{array}{l}\text { Amino acio } \\
\text { ACA GGA }\end{array}$} \\
\hline & & 2780 & GGAATGGGTCGTGGACAGATCCTGTGTTCTTCTATGTCCAGGCCAAAA•CAGGATATGAAA & 2839 & \\
\hline & & & & & G \\
\hline Homo sapiens ( $C A G-)$ & CN414639 & 61 & GGAATGGGTCGTGGACAGATCCTGTGTTCTTCTATGTCCAGGCCAAAA•GATATGAAA & 117 & $\frac{A G A}{R}$ \\
\hline Pongo pygmaeus & CR858259 & 2562 & GGAATGGGTCGTGGACAGATCCTGTGTTCTTCTATGTCCAGGCCAAAA CAGGATATGAAA & 2621 & \multirow{2}{*}{$\frac{A C A G G A}{T G}$} \\
\hline & & & & & \\
\hline Callithrix jacchus & AJ001298 & 188 & GGAATGGGTCGTGGACAGAGCCTGTGTTCTTCTATGTCCAGGCCAAAA CGGGATACGAAA & 247 & \multirow{2}{*}{$\frac{\mathrm{ACG} G \mathrm{GGA}}{\mathrm{T} G}$} \\
\hline & & & & & \\
\hline Sus scrofa & NM_214172 & 2763 & GGAATGGGTCATGGACGGAACCTGTGTTCTTCTACGTCCAGGCCAAAA CGACATATGAAA & 2822 & \multirow{2}{*}{$\frac{A C G \_A C A}{T \quad T}$} \\
\hline & & & & & \\
\hline Equus caballus & CXS96610(EST) & 467 & GAAATGGGTCGTGGACTGATCCTGTGTTCTTCTATGTCCCGGCCAAAA CGACATATGAAA & 526 & \multirow{2}{*}{$\frac{A C G \quad A C A}{T T}$} \\
\hline & & & & & \\
\hline Bos taurus & $\times 54980$ & 554 & GGAATGGGTCGTGGACGGATCCCGTGTTCTTCTACGTTCAGGCCAAGA CGACATATGAGA & 613 & \multirow{2}{*}{$\frac{A C G \quad A C A}{T} \frac{A}{T}$} \\
\hline & & & & & \\
\hline ovis aries & AY162434 & 356 & GGAATGGGTCATGGACGGAGCCTGTGTTCTTCTATGTTCAGGCCAAGA CGACATATGAGA & 415 & ACG ACA \\
\hline & & & & & $\mathbf{T} \mathbf{T}$ \\
\hline Mus musculus & NM_010513 & 2738 & GGAATGGGTCATGGACAGATCCTGTGTTCTTCTATGTCCCCGCCAAAA•CGACGTATGAGA & 2797 & \multirow{2}{*}{$\frac{A C G \quad A C G}{T T}$} \\
\hline & & & & & \\
\hline Rattus norvegicus & NM_052807 & 2783 & GGAATGGGTCGTGGACAGATCCTGTGTTCTTCTATGTCCCAGCCAAAA CAACGTATGAGA & 2842 & \multirow{2}{*}{$\frac{A C A A C G}{T T}$} \\
\hline & & & & & \\
\hline Canis familioris & $X M_{-} 545828$ & 4226 & GGAATGGGTCGTGGACGGATCCTGTGTTCTTCTATGTCCCAGCCAAAA IAACGTATGAAA & 4285 & \multirow{2}{*}{$\frac{A I A \perp A C G}{I T}$} \\
\hline & & & & & \\
\hline
\end{tabular}

Figure 2. Alignment of human IGF1R mRNA sequence, encompassing the $\mathrm{CAG}^{+} / \mathrm{CAG}^{-}$exon/exon junction with the corresponding mRNA sequences from several species. The symbol $\bullet$ is used when the exon/exon junction is known with certainty. Amino acid, predicted amino acid is shown aligned to the first base of its codon; T, threonin, polar not charged; G, glycin, polar not charged; I, isoleucine, not polar; R, arginine, basic.

\begin{tabular}{|c|c|c|}
\hline Species & GenBank $n^{\circ}$ & Amino acid sequence \\
\hline Homo sapiens & NM_000875 & YTARIQATSLSGNGSWTDPVFFYVQ-AKTG-YENFIHLI IALPVAVLLIVGGLVIMLYVFHR \\
\hline Pongo pygmaeus & $\mathrm{CR} \overline{8} 58259$ & YTARIQATSLSGNGSWTDPVFFYVQ-AKTG-YENFIHLI IALPVAVLLIVGGLVIMLYVFHR \\
\hline Sus scrofa & NM 214172 & YTARIQATSLSGNGSWTEPVFFYVQ-AKTT-YENFIHLI IALPVAVLLIVGGLVIMLYVFHR \\
\hline Equus caballus & $\operatorname{cx} \overline{5} 96610$ & YTARIQATSLSGNGSWTDPVFFYVP-AKTT-YENFIHLIIALPVAVLLIV . . . . . . . \\
\hline Bos taurus & $\mathrm{X} 54980$ & YTARIQATSLSGNGSWTDPVFFYVQ-AKTT-YENF IHLMIALPIAVLLIVGGLVIMLYVFHR \\
\hline Mus musculus & NM_010513 & YTARIQATSLSGNGSWTDPVFFYVP-AKTT-YENFMHLI IALPVAILLIVGGLVIMLYVFHR \\
\hline Rattus norvegicus & NM-052807 & YTARIQATSLSGNGSWTDPVFFYVP-AKTT-YENFMHLI IALPVAILLIVGGLVIMLYVFHR \\
\hline Gallus gallus & NM_205032 & YSARVQATSLAGNGSWTEPVSFYVQ-PKS ANYDNFLHLI IVLPIAFLLI IGGLLIMLYVFNK \\
\hline Cynops pyrrhogaster & $\mathrm{AB} \overline{0} 50625$ & YSSQVQA ISLSGTGALTEPIFFYVQ-AKP P DYGKYLLTAIMVPLIALLLLSATILTVCYFNK \\
\hline Danio rerio & NM_152968 & YSARVRATSLAGNGSWTEPVSFYVPPPKRN-YDNALYVAIIIPVIVLLLLLFVIVAVIIVTK \\
\hline Psetta maxima & $\mathrm{AJ} \overline{2} 24993$ & YSVRVRATSLAGNGSWTNAVDLYV--AER--YENVLYAMIFIP IAI ILF ICLLVTMLVVLNK \\
\hline
\end{tabular}

Figure 3. Manual alignment of the vertebrate IGF1R protein sequences available in GenBank (nr or EST divisions). Only the partial amino-acid sequence encompassing the sequence corresponding to the $\mathrm{CAG}^{+} / \mathrm{CAG}^{-}$exon junction is shown.

Although the genomic sequence is not available for the IGFIR locus in other species, as Ovis aries, Bos taurus, Equus caballus and Sus scrofa, the RNA sequence corresponding to the first three bases of human exon 14 is the same (CGA), suggesting consistent intron/exon junctions among all these species.

In Callithrix jacchus, a non-anthropomorphic monkey, the RNA sequence corresponding to the first three bases of human exon 14 is CGG and, in anthropomorphic monkey Pongo pygmaeus (Orangutan) and Homo sapiens, it is CAG. In the last case, at the intron/exon junction, there are two

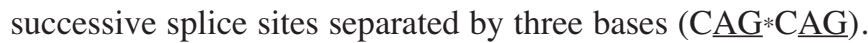
The Genbank numbers of all retrieved sequences are shown in Table II.

Fig. 3 shows the alignment of the vertebrate IGF1R protein sequences available in GenBank (nr or EST divisions). Alignment underlines that the encoded amino acids corresp- onding to the $\mathrm{CAG}^{+} / \mathrm{CAG}^{-}$exon junction in $I G F 1 R$ mRNA are conserved from rodents to humans, but they are different in fishes, amphibians and birds.

\section{Discussion}

The term 'neuroendocrine' has been used to define cells as neurons and endocrine cells that secrete their products in a regulated manner in response to a specific stimulus, and sharing a common phenotypic program characterized by the expression of specific markers, such as neuropeptides and chromogranins (18). Various theories, such as the APUD concept, the diffuse neuroendocrine system (DNES) or the paraneuron concept, have been elaborated to classify neuroendocrine cells as a distinct and cohesive group, while it has been proposed to redefine previous 'neuroendocrine' concepts to include the notion that activation of specific genetic switches 
can lead to the expression of a partial or full neuroendocrine phenotype in a variety of cell types, including immune cells (18).

One type of tumor arising from neuroendocrine cells is known as carcinoid tumor. These are usually slow-growing tumors, mainly found in the gastrointestinal tract and lungs, that can be treated and often cured. However, Kulkinski (in lung) and APUD cells may also give origin to atypical carcinoids (in lung), and to moderately as well as poorly differentiated neuroendocrine tumors (small cell carcinomas). It should therefore be noted that the tumors studied are a mixture of well-differentiated carcinoids and neuroendocrine carcinomas with distinct differentiation grades. A feature of typical carcinoid tumors, except those originating in the rectum, is the cellular production of a variety of endocrine substances, mainly serotonin (5-hydroxytryptamine) and kallikrein (an activator of bradykinin release), leading to carcinoid syndrome (flushing, diarrhea, bronchoconstriction, cardiac valvular lesions, and telangiectasia) (informations in cancernet site: http://www.cancer.gov/cancerinfo/pdq/treatment/gastrointestin alcarcinoid/HealthProfessional).

Based on the proposed role of the IGF1/IGF1R system as a key regulator of mitogenesis and tumorigenicity in the growth of carcinoid tumors $(11,12)$, we have studied the relative expression of IGFIR mRNA splicing isoforms $\mathrm{CAG}^{+}$and $\mathrm{CAG}^{-}$in a large series of human neuroendocrine tumors; $\mathrm{CAG}^{-} \mathrm{CHO}$ cells were previously described to have a 2 -fold stronger induction of activities related to mitogenesis with respect to $\mathrm{CAG}^{+}$in a transfection model (14).

We employed an original semiquantitative RT-PCR approach to measure the different expression levels of the two IGF1R mRNA isoforms in human samples. Our method is mainly based on duplicated reactions for each sample in highly standardized conditions $(2.0 \mu \mathrm{g}$ of starting RNA, large-scale PCR experiments with the same reagent mix) followed by accurate digital measurement of amplification product mass at a cycle distant from PCR plateau attainment. The reliability of the test was confirmed by the following: the absence of differences between tumoral and normal samples in $B 2 M$ expression level, suggesting that comparable expression of the reference house-keeping gene $B 2 M$ may be assumed in the two groups; good consistency among replicate experiments performed for each sample; and excellent precision in RT-PCR product mass measurement via gel imaging allowed by linear regression based on at least four known marker points with a correlation coefficient $\geq 0.99$.

Data about the expression levels of IGFIR in 32 RNA samples from neuroendocrine human tumors of different grade as well as in 9 normal tissues were produced by this method. We found IGF1R mRNA expression in $100 \%$ of our samples, in constrast with data from the series described by Wulbrand et al (13), who reported IGFIR mRNA expression in $67-90 \%$ of samples from comparable tumor types.

The first main finding is that neuroendocrine tumor cells express $I G F 1 R \mathrm{CAG}^{+}$mRNA at a significantly higher level than normal tissue cells, with a consistent 2-fold mean increase. The IGFIR $\mathrm{CAG}^{-}$isoform RNA was also expressed at a significantly higher level in tumoral cells than in normal cells, although its amount was lower than the $\mathrm{CAG}^{+}$isoform. It is worth noting that the $\mathrm{CAG}^{-}$form has been demonstrated to elicit mitogenic activities with a double intensity than the $\mathrm{CAG}^{+}$isoform. These data highlight a role for IGF1/IGF1R system in neuroendocrine tumor cells biology.

The second main finding is that, when considering the $\mathrm{CAG}^{+}: \mathrm{CAG}^{-}$ratio of the $I G F I R$ isoforms in tumoral and normal cells, an approximate 3:1 ratio was found in both cell types. This finding suggests that the biology of neuroendocrine tumor cells, while showing an increase in IGFIR mRNA level, still stringently maintains the same $I G F 1 R \mathrm{CAG}^{+}: \mathrm{CAG}^{-}$ratio present in normal tissue, suggesting that this ratio may be tightly regulated in both normal and neoplastic cells. This reinforces the notion that 'subtle' splicing (17), a novel concept of alternative splicing leading to mRNA isoforms different by only three bases, is a non-random method of RNA splicing regulation, and that this type of splicing may lead to the regulated production of protein isoforms different by one amino acid.

In addition, while a previous study has demonstrated higher activity in the signal transduction of the transfected

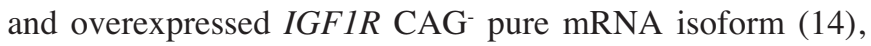
our measurement of the naturally occurring expression ratio of both $\mathrm{CAG}^{+}$and $\mathrm{CAG}^{-} \mathrm{mRNA}$ isoforms lead to the prediction that, if the relative aliquot of $\mathrm{CAG}^{+}$and $\mathrm{CAG}^{-}$derived receptor chains is proportional to mRNA and if the dimerization of these two protein types is allowed, the IGF1R dimerized receptor could be of three types: $\mathrm{CAG}^{+} / \mathrm{CAG}^{+}, \mathrm{CAG}^{+} / \mathrm{CAG}^{-}$ or $\mathrm{CAG}^{-} / \mathrm{CAG}^{-}$. The proportions of these types depend on the probability of association due to the relative frequency of each form.

Finally, we present a phylogenetic analysis to assess the evolution of this particular type of splicing in the species whose sequence data were available. In the region corresponding to the $\mathrm{CAG}^{+} / \mathrm{CAG}^{-}$alternative splicing site of the human $I G F I R$ receptor, a nucleotide change in the rat eliminates the alternative acceptor splice site (19); analysis at RNA level also rules out the possibility to give rise to $I G F 1 R$ $\mathrm{CAG}^{+} / \mathrm{CAG}^{-}$isoforms for Ovis aries, Bos taurus, Equus caballus and Sus scrofa mammalian species. Only in humans and in the anthropomorphic monkey, Pongo pygmaeus, did the physical base for a 'subtle' alternative splicing appear, via the creation of two successive splice sites separated for three bases $(\mathrm{CAG} * \underline{\mathrm{AG}})$ at the boundary of IGFIR locus intron 13/exon 14. The phylogenetic study of this locus may explain why human IGFIR $\mathrm{CAG}^{+} \mathrm{mRNA}$ isoform is prevalent on the $\mathrm{CAG}^{-}$isoform, because the second splice site leading to the $\mathrm{CAG}^{-}$isoform is more recent from an evolutionary point of view and it could be used by the splicing apparatus at this intron/exon junction with a lower efficiency than the previous conserved site. Interestingly, while the IGF1R proteins share a very similar sequence from fishes to humans, the encoded amino acids corresponding to the $\mathrm{CAG}^{+} / \mathrm{CAG}$ exon junction in the IGFIR mRNA are conserved from rodents to humans, but they are different in fishes, amphibians and birds. Further studies are needed to explore the fine regulation and consequences for cell growth and biology of the presence of different IGFIR mRNA isoforms leading to receptor variants different by one amino acid ('subtle' alternative splicing).

In conclusion, this work highlights the relevance of 'subtle' alternative splicing for the IGFIR locus, showing overexpression of both mRNA isoforms in a large series of 
human neuroendocrine tumors in the presence of a constant relative expression of the two isoforms.

\section{Acknowledgements}

This work was supported by grants from MURST 'ex 60\%' to P.S.

\section{References}

1. Ullrich A, Gray A, Tam AW, Yang-Feng T, Tsubokawa M, Collins C, Henzel W, Le Bon T, Kathuria S, Chen E, et al: Insulin-like growth factor I receptor primary structure: comparison with insulin receptor suggests structural determinants that define functional specificity. EMBO J 5: 2503-2512, 1986.

2. Sekharam M, Zhao H, Sun M, Fang Q, Zhang Q, Yuan Z, Dan HC, Boulware D, Cheng JQ and Coppola D: Insulin-like growth factor 1 receptor enhances invasion and induces resistance to apoptosis of colon cancer cells through the Akt/Bcl-x(L) pathway. Cancer Res 63: 7708-7716, 2003.

3. Hakam A, Yeatman TJ, Lu L, Mora L, Marcet G, Nicosia SV, Karl RC and Coppola D: Expression of insulin-like growth factor-1 receptor in human colorectal cancer. Hum Pathol 30: 1128-1133, 1999

4. Long L, Rubin R, Baserga R and Brodt P: Loss of the metastatic phenotype in murine carcinoma cells expressing an antisense RNA to the insulin-like growth factor receptor. Cancer Res 55: 1006-1009, 1995.

5. Trojan J, Johnson TR, Rudin SD, Ilan J, Tykocinski M and Ilan J: Treatment and prevention of rat glioblastoma by immunogenic C6 cells expressing antisense insulin-like growth factor I RNA. Science 259: 94-97, 1993.

6. Ambrose D, Resnicoff M, Coppola D, Sell C, Miura C, Jameson S, Baserga $\mathrm{R}$ and Rubin R: Growth regulation of human glioblastoma T98G cells by insulin-like growth factor-1 and its receptor. J Cell Physiol 159: 92-100, 1994.

7. Pietrzkoski Z, Mulholland G, Gomella L, Jameson BA, Wernicke D and Baserga R: Inhibition of growth of prostatic cancer cell lines by peptide analogues of insulin-like growth factor 1. Cancer Res 53: 1102-1106, 1993.

8. Resnicoff M, Ambrose D, Coppola D and Rubin R: Insulin-like growth factor- 1 and its receptor mediate the autocrine proliferation of human ovarian carcinoma cell lines. Lab Invest 69: 756-760, 1993.
9. Resnicoff M, Coppola D, Sell C, Rubini R, Ferrone S and Baserga R: Growth inhibition of human melanoma cells in nude mice by antisense strategies to the type 1 insulin-like growth factor receptor. Cancer Res 54: 4848-4850, 1994

10. Adachi Y, Lee CT, Coffee K, Yamagata N, Ohm JE, Park KH, Dikov MM, Nadaf SR, Arteaga CL and Carbone DP: Effects of genetic blockade of the insulin-like growth factor receptor in human colon cancer cell lines. Gastroenterology 123: 1191-1204, 2002.

11. Von Wichert G, Jehle PM, Hoeflich A, Koschnick S, Dralle H, Wolf E, Wiedenmann B, Boehm BO, Adler G and Seufferlein T: Insulin-like growth factor-I is an autocrine regulator of chromogranin A secretion and growth in human neuroendocrine tumor cells. Cancer Res 60: 4573-4581, 2000.

12. Van Gompel JJ and Chen H: Insulin-like growth factor 1 signaling in human gastrointestinal carcinoid tumor cells. Surgery 136: 1297-1302, 2004.

13. Wulbrand U, Remmert G, Zofel P, Wied M, Arnold R and Fehmann HC: mRNA expression patterns of insulin-like growth factor system components in human neuroendocrine tumours. Eur J Clin Invest 30: 729-739, 2000.

14. Condorelli G, Bueno R and Smith RJ: Two alternatively spliced forms of the human insulin-like growth factor I receptor have distinct biological activities and internalization kinetics. J Biol Chem 269: 8510-8516, 1994.

15. Engels WR: Contributing software to the internet: the Amplify program. Trends Biochem Sci 18: 448-450, 1993

16. Sharrocks AD: The design of primer for PCR. In: PCR Technology - Current Innovations. Griffin HG, Griffin AM (eds). CRC Press, Boca Raton, pp5-11, 1994.

17. Hiller M, Huse K, Szafranski K, Jahn N, Hampe J, Schreiber S, Backofen R and Platzer M: Widespread occurrence of alternative splicing at NAGNAG acceptors contributes to proteome plasticity. Nat Genet 36: 1255-1257, 2004. Erratum in: Nat Genet 37:106, 2005 .

18. Day R and Salzet M: The neuroendocrine phenotype, cellular plasticity, and the search for genetic switches: redefining the diffuse neuroendocrine system. Neuroendocrinol Lett 23: 447-451, 2002.

19. Pedrini MT, Giorgino F and Smith RJ: cDNA cloning of the rat IGF I receptors: structural analysis of rat and human IGF I and insulin receptors reveals differences in alternative splicing and receptor-specific domain conservation. Biochem Biophys Res Commun 202: 1038-1046, 1994. 